\title{
HUMAN MYIASIS: CLINICAL CASE
}

\section{ORIGINAL ARTICLE}

SILVA, Agnaldo Plácido da ${ }^{1}$, PLÁCIDO, Eloá Jessica Mendes dos Santos², MORAES, Walber Breno de Souza ${ }^{3}$

SILVA, Agnaldo Plácido da. PLÁCIDO, Eloá Jessica Mendes dos Santos. MORAES, Walber Breno de Souza. Human myiasis: Clinical case. Revista Científica Multidisciplinar Núcleo do Conhecimento. Year 05, Ed. 08, Vol. 10, pp. 39-46. August 2020.

ISSN: 2448-0959, Access Link: https://www.nucleodoconhecimento.com.br/health/human-myiasis, DOI: 10.32749/nucleodoconhecimento.com.br/health/human-myiasis

\section{ABSTRACT}

Myiasis is considered a dermatozoonosis infestation caused by infestation of dipteran larvae in tissues or organs, which lay their eggs in humans or animals, which for a certain period feed on living or dead tissues of the host the occurrence of myiasis in the oral cavity can be considered a rare thing. This type of disease most often affects people of low socioeconomic status, immunocompromised, bedridden elderly and with psychiatric disorders. Due to its great destructive potential, a timely and important appropriate prevention and treatment, there is also little knowledge of the dental professional for the diagnosis and treatment of such pathology, For this reason, the present study reports a clinical case of oral myiasis in an elderly person bedridden with a history of malignant laryngeal/glottal neoplasia injury, presenting physical and mental weakness and inadequate body hygiene and lack of lip sealing that led to the infestation of larvae in the tongue. The diagnosis was clinically

\footnotetext{
${ }^{1}$ PhD student in Biomedical Sciences at IUNIR - Italian University Institute of Rosario - Argentina. Specialist in Bucomaxillofacial Surgery and Traumatology by Ciodonto - Integrated Dentistry Clinic. Graduated in dentistry from ASCES - Caruaruense Association of Higher Education. Graduated in Biologist from UPE - University of Pernambuco.

${ }^{2}$ Graduated from the Physiotherapy Course of UNINASSAU College.

${ }^{3}$ Degree in Biology UPE- University of Pernambuco. Master in Natural Resources - UFCG. Professor at UNOPAR.
} 
established based on observation of tongue bleeding, tissue detachment, and presence of larvae that were between the second and third stages of development. Treatment was initiated as hospitalization of the patient for debridement of necrotic tissues and removal of larvae and prescription of ivermectin. Bedridden patients with physical and metal weakness constitute a risk group for oral myiasis, and it is of great importance to guide caregivers and family members in relation to dental care in order to prevent this pathology. However, the lack of a consensus on the best therapeutic approach for cases of oral myiasis was taken as therapeutic conduct for the disease the mechanical removal of larvae and institution of oral use of ivermectin.

Keywords: Larva, human myiasis, flies, public health.

\section{INTRODUCTION}

Myiasis is defined as a pathology in which there is pestilence of larvae of flies that feed on living or dead tissues (VINIT; JAYAVELU and SHRUTHA, 2013), although this parasitosis has been described for many years by researchers, the technical term for designating the bicheira was suggested in 1840 by Reverend F. W. Hope in his work "On insects and their larvae occasionally found in the human body", where it is proposed the use of the term "myiasis", which is derived from the Greek words myia (fly) and ase (disease) (GUIMARAES; PAPAVERO and PRADO, 1983). In Hindu literature myiasis was considered by mythology as punishment of sinners (PARMAR; DAVESSAR et al., 2018).

Patients with myiasis generally present some factors that lead to predisposition to their development, such as mental retardation, psychiatric disorders, senility, vascular diseases, neoplasms, diabetes and immunodepression and chronic alcohol consumption, and occurs preferably in the elderly. (MARQUEZ; MATTOS and NASCIMENTO, 2007) (SILVEIRA; PINHEIRO et al., 2015) However, the factors of greatest relevance for the onset of Myiasis are still the occurrence of exposed lesions with exudations and poor body and oral hygiene (NASCIMENTO; OLIVEIRA et al., 2005) (TOURÉ, 1994). 
This is a situation of fatal severity for the patient, in addition to causing pain and tissue destruction. Oral myiasis may present as laceration of the oral cavity, swelling of the oral mucosa, inflammation of the gingival (RIBEIRO; PEREIRA et al., 2001). "In the case of Myiasis cavitaria, which comprises the regions of the mouth and nose and paranasal sinus, it can be affirmed that it is a very rare type of myiasis" (BARNABÉ; FERRAZ et al., 2016). The most prevalent variety of fly species responsible for most cases of myiasis includes Cochliomyia hominivorax, Chrysomya bezziana, Oestrus ovis, Magnificent Wohlfahrtia and the domestic Musca. The incidence of infection is rare even in developing countries (KHAN; SABIR et al., 2018) (TOURÉ, 1994).

The treatment for myiasis basically consists of the manual removal of larvae, with the help of cureta and clinical tweezers, usually under anesthesia or analgesia, depending on the clinical status of the patient, the removal of the larvae te that be done carefully, so that the lavas are not fragmented, and their remains remain in place, generating an infectious process (CAVALCANTI, 2008), although there are some products on the market that can be used to facilitate removal (BARNABÉ; FERRAZ et al., 2016), the literature reports very successfully the systemic use of a dose of ivermectin, a semisynthetic macrolide antibiotic for the treatment of more severe cases involving the existence of oral myiasis, demonstrating to be a safe method at the recommended dosages of $200 \mu \mathrm{g} / \mathrm{kg}$. Even at dosages of 300 or 400 $\mu \mathrm{g} / \mathrm{kg}$, patients submitted to treatment did not present any important clinical side effect, other than mild itching (GEALH; FERREIRA et al., 2009) (RIBEIRO; PEREIRA et al., 2001).

We can classify Myiasis into three different types: biontophagous or primary which are those dipteran larvae that develop on or within vertebrates, feeding on the tissues of the living host. Among these species, we can find Cochliomy homini vorax and Dermatobia hominis. Secondary necrobiollins are those in which dipteran larvae develop into organic matter that is already decomcomposition (cadavers), acting as saprophagous, but can also affect necrotic tissues in a living host. The most common genera are: Lucília, Phaenicia, Musca and Fannia. Pseudomyiasis (accidental): this 
may occur by ingestion of egg and/or dipteran larvae present in contaminated food ingested by the host, causing an intestinal disorder (CAVALCANTI, 2008) (BOROS; BOROS et al., 2006).

\section{CLINICAL CASE}

A 69-year-old male patient diagnosed with malignant neoplasm in the tongue (undergoing chemotherapy) was admitted to the emergency room of the Dom Moura Regional Hospital in Garanhuns - Pernambuco complaining of pain and infrequenting in the mouth region for several weeks, was referred to the Bucomaxillofacial Surgery and Traumatology service. On admission, the patient was afebrile, oriented and cooperative, bleeding was observed in the mouth, considering the family's report that the patient had dental problems, and examinations were performed. In the intraoral evaluation showed a well-defined ulcerative lesion with central necrotic tissue and several live larvae on the tongue. (Figure 1) 
Figure 1 - Larvae on the tongue.

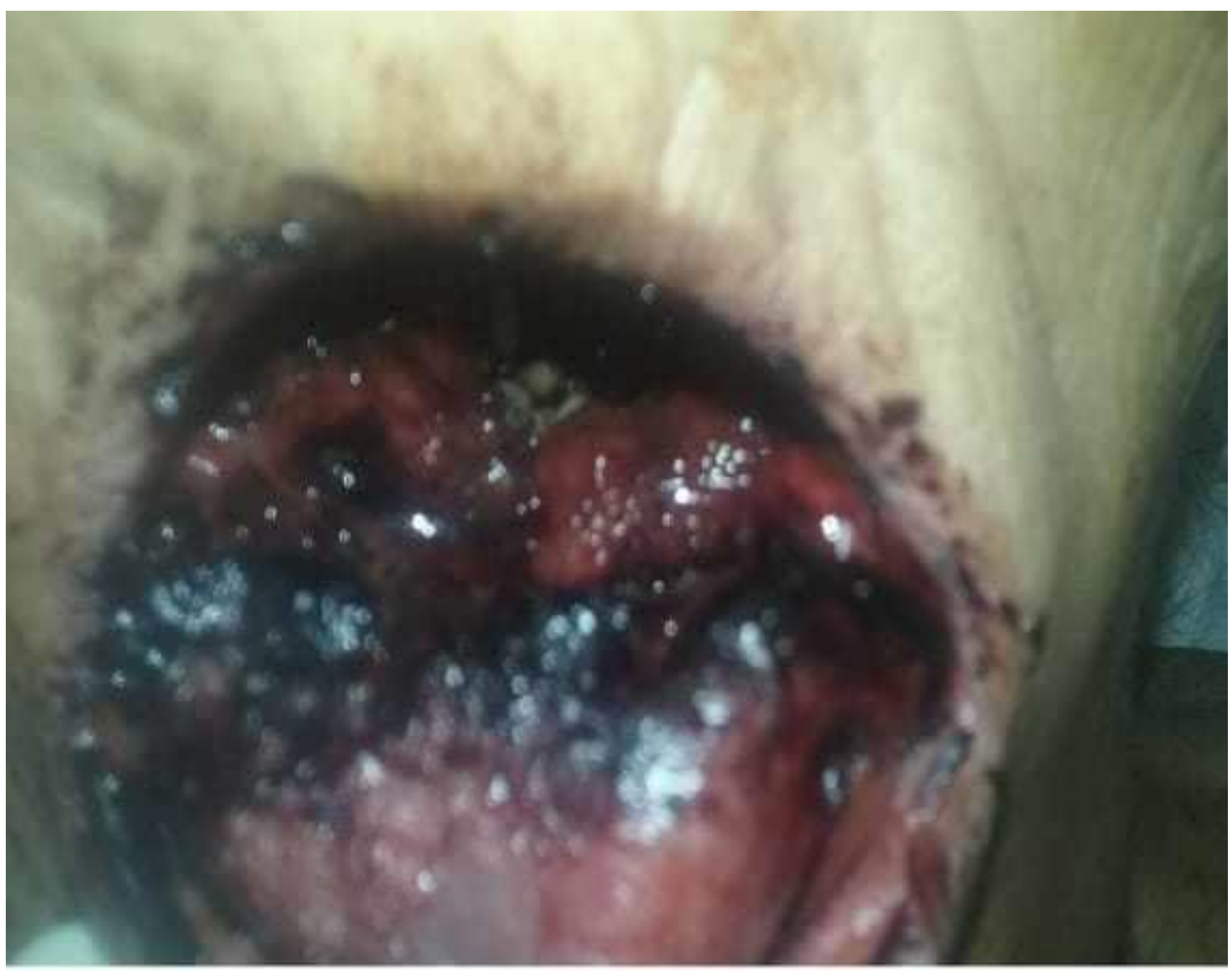

Source: The authors (2020).

The patient affected by the disease presented predisposing factors such as physical and mental weakness, dehydration, inadequate body hygiene, diabetes, malnutrition, mouth breathing during sleep and poor maintenance of oral hygiene.

Thus, primary symptomatic treatment was performed. The wound was cleaned and disinfected with $0.12 \%$ Chlorhexidine solution. The larvae were manually removed under local anesthesia with the help of clinical tweezers, the whole aseptic field, the larvae in this case were collected and placed in a clinical tray. Approximately 80 larvae were removed from the region, and all of them could not be removed (Figure 2). 
Figure 2 - Larvae removed from the lesion

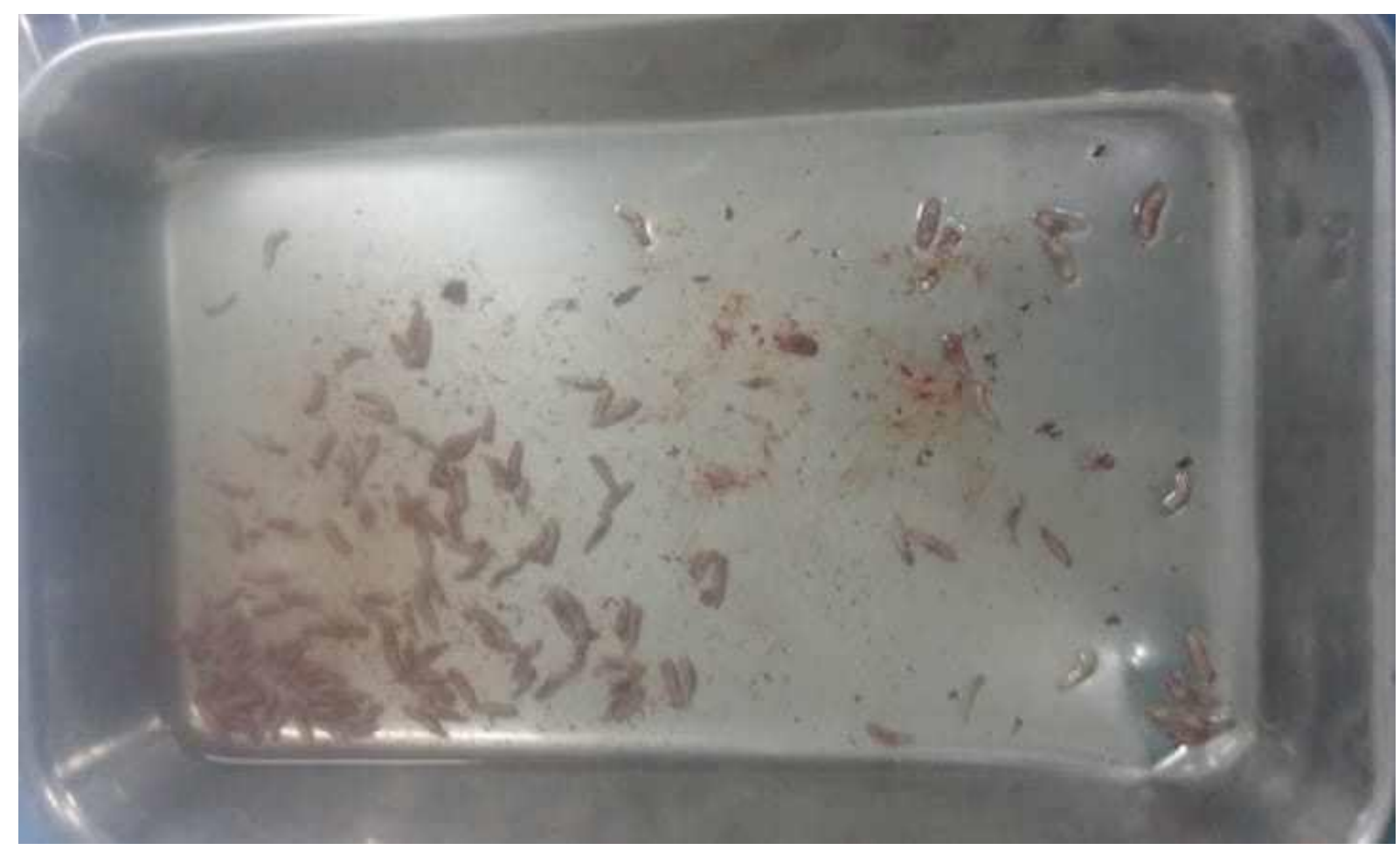

Source: The authors (2020).

The patient was hospitalized and intravenous antibiotic therapy was started Cephalotin 1g, Dipirona and Ketoprofen, and a single oral dose of Ivermectin two tablets, i.e., $12 \mathrm{mg}$ (approximately $200 \mu \mathrm{g} / \mathrm{kg}$ ), After 10 days all remaining larvae had been eradicated, with no need for complementation of Ivermectin.

\section{DISCUSSION}

During the process of development of larvae, adjacent tissues present inflammatory process, with or without ulceration or necrosis of tissues (CARVALHO; SANTOS et al., 2008). Many serious complications can occur due to myiasis: cellulitis, erosion of bones and teeth, bacteremia and death (SZAKACS and MACPHERSON, 2007).

In many of the articles consulted, we observed that the authors mention that oral myiasis is a rare pathology, and that dipterans have no preference for age, sex and ethnicity. And that the infestation of the larva of dipterans is more in the rural area, 
infesting domestic animals such as dogs, cats, pigs, ox. The general opinion of the authors is that people who were infested by larvae are mentally handicapped, people with little body and oral hygiene, such as low level of education, people of low socioeconomic status (BOROS; BOROS et al., 2006).

The diagnosis of human myiasis is clinical, so that one can detect some of its complications may be necessary to perform computed tomography, ultrasound or magnetic resonance imaging (SHENOUDA; ENTEN et al., 2018).

The presence of larvae on the skin triggers a local inflammatory response with the migration and proliferation of inflammatory cells such as neutrophils, mast cells, eosinophils, fibroblasts and endothelial cells. However, the complete blood cell count may show high levels of leukocytes and eosinophils (PAYNE and COSGROVE, 1966) (SHENOUDA; ENTEN et al., 2018).

Some authors advocate a conventional treatment of myiasis, which includes the removal of larvae with the help of chemical substances, which aims to promote the asphyxia of larvae inducing their exit from the lesion. In larger lesions where it presents a clinical picture of adjacent cellulitis, a debridement of local tissues would be indicated with the removal of necrotic tissues, but others defend as ideal, the surgical treatment, which allows the removal of all larvae allied to a debridement, and antibiotics to prevent secondary infection, another method have already been tried as the use of a single dose of ivermectin (PARMAR; DAVESSAR et al., 2018).

Myiasis can be seen as a public health problem that can be prevented by eliminating risk factors for human health, such as lack of basic sanitation and inadequate disposal of garbage, where organic material is exposed, which attracts insects and small animals, creating a sustainable cycle of dirt. Poor sanitation is probably the most important risk factor for human myiasis (FRANCESCONI and LUPI, 2012). 


\section{CONCLUSION}

In the literature, several treatments for cavitary myiasis have been proposed, ranging from mechanical extraction to the use of topical, oral and intravenous substances. But an early and correct diagnosis allows a treatment with a favorable prognosis. However, whatever the means employed, it is essential that the patient is oriented regarding the adoption of appropriate personal hygiene measures. However, there is no consensus on the best therapeutic approach for cases of oral myiasis.

\section{REFERENCES}

BARNABÉ, A. S. et al. Epidemiologia Da Miíase Cutânea: Revisão Da Literatura. Atas de Ciências da Saúde, São Paulo, v. 4, n. 2, p. 14-22, Abril - Junho 2016.

BOROS, L. F. et al. Miíase Labial. Revista Dens, v. 14, n. 1, p. 1-10, Revista Dens, v.14, n.1, maio/outubro 20062006.

CARVALHO, R. W. F. et al. Oral and maxillofacial myiasis associated with epidermoid carcinoma: a case report. Journal of Oral Science, v. 50, n. 1, p. 103-105, 2008.

CAVALCANTI, A. L. Miíase Oral: etiologia, diagnóstico e tratamento. Rev. Fac. Odontol. Porto Alegre, Porto Alegre, v. 49, n. 2, p. 32-35, maio/ago. 2008.

CAVALCANTI, A. L. Miíase Oral: etiologia, diagnóstico e tratamento. Rev. Fac. Odontol. Porto Alegre, Porto Alegre, v. 46, n. 2, p. 32-35, maio/ago. 2008.

FRANCESCONI, ; LUPI,. Myiasis. Clinical Microbiology Reviews , v. 25, n. 1, p. 79 105, Jan. 2012.

GEALH, W. C. et al. Treatment of oral myiasis caused by Cochliomyia hominivorax: two cases treated with ivermectin. British journal of Oral and Maxillofacial Surgeons, v. 47, n. 1, p. 23-26, January 2009. 
GUIMARAES, J. H.; PAPAVERO, ; PRADO, A. P. D. As Mi1ases Na Região Neotropical. Revista Brasileira De Zoologia (Identificação, Biologia, Bibliografia), São Paulo, v. 1, n. 4, p. 239.416, 1983.

KHAN, B. A. et al. Oral and cutaneous myiasis in a 5 year old child from Karachi, Pakistan. Le Infezioni in Medicina, v. 4, p. 385-388, 2018.

MARQUEZ, A. T.; MATTOS, M. D. S.; NASCIMENTO, S. B. Miíases associadas com alguns fatores sócio-econômicos em cinco áreas urbanas do Estado do Rio de Janeiro. Revista da Sociedade Brasileira de Medicina Tropical, v. 40, n. 2, p. 175180, março - abril 2007.

NASCIMENTO, E. M. F. D. et al. Miíases Humanas Por Cochliomyia Hominivorax (Coquerel, 1858) (Diptera, Calliphoridae) Em Hospitais Públicos Na Cidade Do Recife, Pernambuco, Brasil. Entomología y Vectores, v. 12, n. 1, p. 37-51, 2005.

PARMAR, S. et al. Tracheostomal Myiasis: A Case Report And Review Of Literature. International Journal of Scientific Research, v. 7, n. 12, p. 4-6, December 2018.

PAYNE, J. A.; COSGROVE, G. E. Tissue changes following Cuterebra infestation in rodents. The American Midland Naturalist, v. 75, n. 1, p. 205-213, Jan. 1966.

RIBEIRO, F. A. Q. et al. Tratamento da miíase humana cavitária com ivermectina oral. Rev Bras Otorrinolaringol, v. 67, n. 6, p. 755-761, nov./dez. 2001.

SHENOUDA, M. et al. Human Botfly: A Case Report and Overview of Differential Diagnosis. J Investig Med High Impact Case Rep., v. 6, Jan-Dec; 2018.

SILVEIRA, M. A. A. et al. Cavitary myiasis mimicking peritonsilar abscess. Brazilian Journal of Otorhinolaryngology, v. 81, p. 336-338, 2015.

SZAKACS, T. A.; MACPHERSON,. Nosocomial myiasis in a Canadian intensive care unit. CMAJ, v. 177, n. 7, p. 719-720, 25 September 2007. 
TOURÉ, S. M. Les myiases d'importance économique. Rev. sci. tech. Off. int. Epiz., 1994, 13 (4), 1053-1073, v. 13, n. 4, p. 1053-1073, 1994.

VINIT, G. B. ; JAYAVELU, P.; SHRUTHA, S. P. Oral myiasis in a maxillofacial trauma patient. J Pharm Bioallied Sci., v. 5, n. 6, p. 195-197, 5 Jul 2013.

Sent: February, 2020.

Approved: August, 2020. 